\title{
CHEMICAL-PHYSICAL AND ECOLOGICAL CHARACTERISATION OF A POLLUTED COASTAL AREA: THE MANZALA LAKE OF EGYPT, CASE STUDY
}

\author{
Orabi H. Orabi, Kamal A. Dahab, Hekmat F. Abdella and Mostafa M. El-Sehamy \\ Geology Department, Faculty of Science, Menoufia University, Egypt
}

\begin{abstract}
The present study on the Manzala Lake is to define the environmental state, where the freshwater mollusks play significant roles in the public and veterinary health. Moreover the benthic foraminifers are affected by environmental changes and can be used as bio-indicators of pollution in coastal environments. Several physical and chemical factors are considered as affecting the ecology of snails and other intermediate hosts of diseases have been studied in the present work.

The Recent sediment reported in the Manzala Lake illustrated that the whole area is characterized by relatively coarser fractions (silty sand) and located at the western part of the lake.

The regional pollution index (RPI) of the studied Manzala Lake bottom sediments are exposed to high pollution levels by $\mathrm{Cd}, \mathrm{Pb}, \mathrm{Ni}$ and $\mathrm{Co}$. Meanwhile, $\mathrm{Zn}$ and $\mathrm{Cu}$ display low degree of pollution. The highest values of heavy metals are recorded near El-Serw agricultural drain and also, at eastern portion of the lake near Bahr El-Baqar agricultural drain where the industrial region in Port Said country.
\end{abstract}

Keywords: Manzala Lake, Snail, Heavy metals, Bio-indicator, Pollution.

\section{INTRODUCTION}

Anthropogenic induced pollution is one of the most important problems threatening the Manzala Lake ecosystems. The modification and destruction of coastal habitats through improper development practices and poor management are very significant problems.

Many drains transport water from the eastern delta to the lake, carrying large amounts of particulate matter, nutrients, bacteria, heavy metals, and toxic organics. Methane and hydrogen sulfide bubble up to the surface, releasing greenhouse gases. Therefore, poor water quality of lake threatens wildlife, ecosystems, and the health and livelihood of people in the area, while polluting Mediterranean Sea.

The sediments act as "sink" for heavy metal contaminants, and risk increases with increasing metals leachability. The impact of such heavy metals abnormality may extend to involve the water quality and food web, and hence to the human health. In the studied area, sources of the toxic metals could be natural or anthropogenic. This is contributed by industrial, domestic, human activities, sewage and huge amounts of agriculture brackish water wastes from drainage system at all direction.

Many of the pollutants are toxic to aquatic organisms causing their lethal or sub lethal deterioration. The toxic effect depends mainly on the type of the pollutant and on its concentration. In most of the cases the concentrations of the pollutants are low, causing only sub-lethal or chronic disease nevertheless, acute massive pollution resulting fish-kill or death of various organisms, may also occur in rivers or lakes. Contamination of aquatic ecosystems (e.g. lakes, rivers, stream, lagoons, oceans etc.) with metals has been receiving increased worldwide attention (Diagomanolin et al., 2004; Singh et al., 2004 and Farkas et al., 2007).

The main objective of this study is the preparation of a sustainable development plan for the area, elaboration of methodological procedures for implementation and reliability and to assess the distribution pattern of the lake heavy metals according the international constrains imposed by the Egyptian standards and the world-wide organizations. 
Orabi, et al

One of the specific objectives of the Manzala Lake study is to define the environmental state and to identify protection policies, where the freshwater mollusks have been known to play significant roles in the public and veterinary health and thus need to be scientifically exploring more extensively. Moreover because of foraminiferal short life cycles and special habitat requirements, benthic foraminifers are affected by environmental changes and can be used as bio-indicators of pollution in coastal environments (Ferraro et al., 2006). Morphological abnormalities in foraminifer tests are observed in polluted environments and may represent a useful bio-marker for evaluating long-term environmental impacts (Vilela et al., 2004).

\section{Study area}

The Manzala Lake is the largest Egyptian coastal lake; it lies on the eastern north coast of Egypt (Fig. 1), has a dimensions of about $47 \mathrm{Km}$ long and $30 \mathrm{Km}$ wide. This lake serves five provinces of Nile Delta (Damietta, Dakahliya, Sharkiya, Ismailia and Port Said). Economically, Manzala Lake is considered as one of the most valuable fish sources in Egypt. The northern boundary of the lake is the Mediterranean Sea (there are some narrow outlets, the main outlets are El-Gamil outlet and the New El-Gamil Outlet), while the eastern boundary is Suez Canal. Damietta Branch of River Nile is considered its western boundary.

The western and southern shores of the Manzala Lake have many inlets by which great amounts of water drain into the lake. The most important agricultural drains are Bahr El-Baqar, Hadous, Ramsis, ElSirw, and Faraskur. A total of 3.7 billion cubic meters of water (mostly from agricultural drainage) flow annually into Manzala Lake from the major drains and canals. The drained waters can be classified as an agricultural, industrial and domestic waste. Water fluctuated from low salinity in the south and west to brackish water over the most of its area to saline water in the extreme northwest. Bahr El-Baqar Drain has the most polluted drain discharges into Manzala Lake. Major pollutants in agricultural drains are salts; nutrients (phosphorus and nitrogen); pesticide residues (from irrigated fields), pathogens (from domestic wastewater) and toxic organic and inorganic pollutions (from domestic and industrial sources).

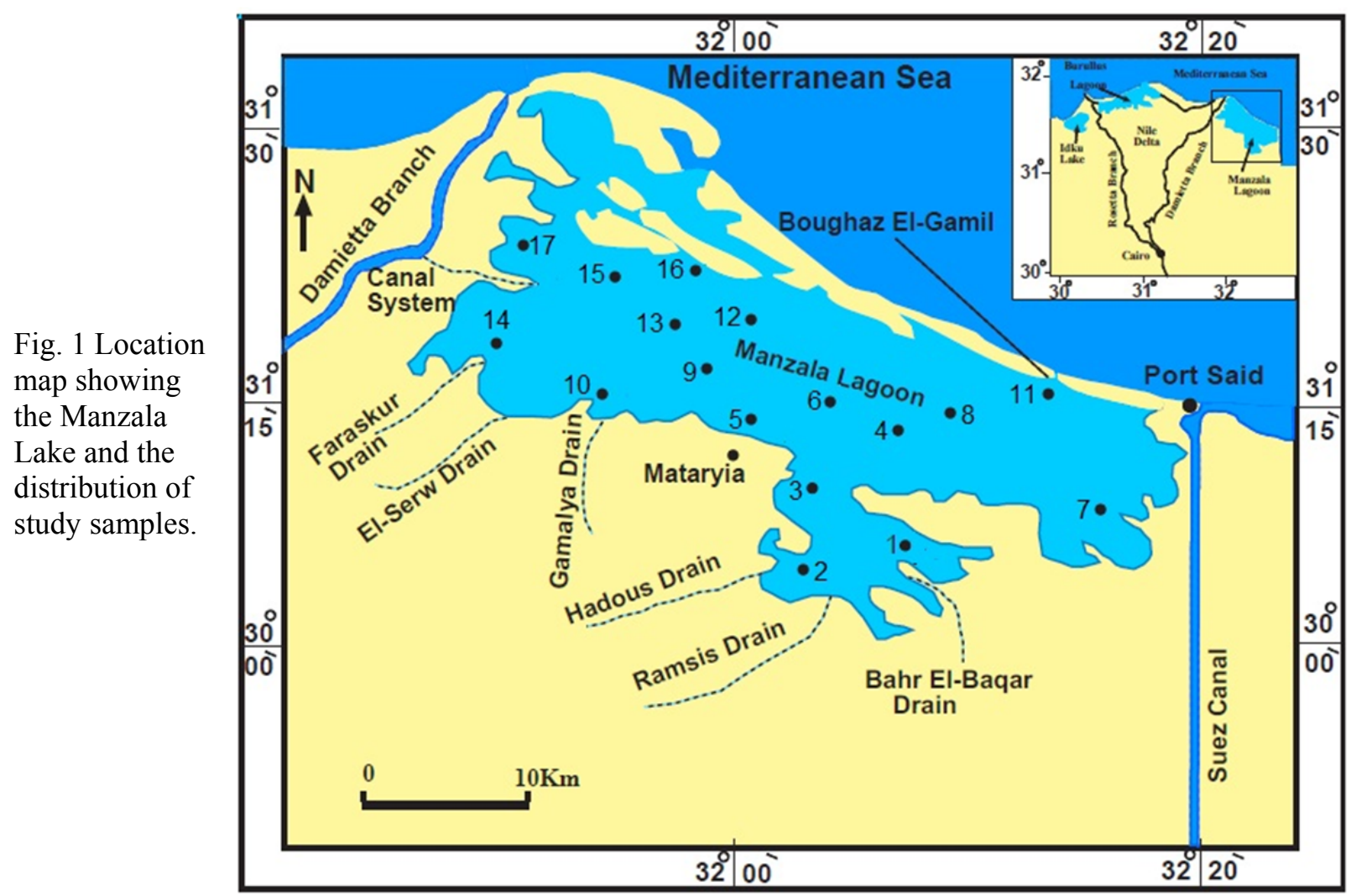




\section{Chemical-physical and ecological characterisation}

\section{MATERIALS AND METHODS}

The recent bottom sediments were collected from seventeen selected stations in the Manzala Lake along selected profiles in order to cover his whole area (Figure 1). The bottom sediments were collected from Manzala Lake using a grab sample (Ekman type), which was immersed to the depth ranging between 20 centimeters and 200 centimeters.

The statistical parameters of the bottom sediments were calculated following the equations proposed by Folk and Ward (1957) and Folk (1966). The distributions of the texture of the bottom sediments have been made by triangular diagram proposed by Pettijohn et al. (1972) to detect the sediment types.

Water temperature was measured using $0.1^{\circ} \mathrm{C}$ graduated thermometer. Circular White Secchi Disc 25 $\mathrm{cm}$ in diameter was used for determining the turbidity of water. The $\mathrm{pH}$ values were measured by using a portable glass electrode $\mathrm{pH}$ meter (Lutron Research model 206). Dissolved oxygen was determined by the Azide modification of Winkler method according to APHA (1998).

The chemical analyses of cadmium, lead, zinc, nickel, copper, manganese and iron concentrations in the surface bottom sediments were measured by inductively coupled plasma atomic absorption (ICP-AES) using a Varian Vista MPX. All calibration standards were prepared in the same acid matrix used for the sediment samples.

Investigation of foraminifera and molluscan populations was performed on dead individuals. The samples were hand collected using a spoon; a total of 20 gr of each wet sample was soaked in $7 \%$ hydrogen peroxide $\left(\mathrm{H}_{2} \mathrm{O}_{2}\right)$ solution for 24 hours. Then, the samples were dried after flushing under pressurized water in a sieve with a $0.063 \mathrm{~mm}$ mesh size. Carbon tetrachloride was added to the dried samples to bring foraminifer populations in the material to the surface. The foraminifer specimens were collected on filter paper and separated by size using different sieves with $2.00,1.00,0.500,0.250,0.125$ and $0.063 \mathrm{~mm}$ mesh size. The mollusk populations were directly collected from the $0.063 \mathrm{~mm}$ mesh size sieve. The samples were analyzed under a binocular microscope. Species were photographed using JEOL JSM-5300 Scanning Electron Microscope of the Faculty of Science, Alexandria University.

\section{RESULTS}

\section{Sediment types}

Table 1 shows the results of statistical parameters of the sediments collected in summer season where, the sediments of the studied lake are characterized by median diameter (Mdø) varying from $-0.47 \varnothing$ to 4.82 $\varnothing$ with an average $3.5 \varnothing$. However, the mean size (MZø) ranged from $-0.15 \varnothing$ to $5.09 \varnothing$ with an average $3.3 \varnothing$. The inclusive sorting $(\sigma 1)$ varies between $0.94 \varnothing$ to $2.76 \varnothing$ with an average $1.9 \varnothing$ (i.e. moderately sorted to very poorly sorted sediments).

Table 1: Results of mechanical analysis and their corresponding calculated statistical parameters.

\begin{tabular}{|c|c|c|c|c|c|c|c|c|c|c|}
\hline Station & Depth $(\mathrm{cm})$ & $\mathrm{Md} \varnothing$ & $\mathrm{MZ} \varnothing$ & $\sigma_{\mathrm{T}}$ & $\mathrm{Sk}_{1} \varnothing$ & $\mathrm{KG} \varnothing$ & Sand $\%$ & Silt \% & Clay \% & Sediment Types \\
\hline 1 & 75 & 4.767 & 4.78 & 1.08 & 0.08 & 3.26 & 8 & 88.78 & 2.63 & Silt \\
\hline 2 & 100 & 4.825 & 4.31 & 2.74 & -0.3 & 1.01 & 25.64 & 66.6 & 2.04 & Sandy silt \\
\hline 3 & 130 & 4.711 & 4.22 & 1.75 & -0.46 & 3.58 & 19.52 & 75.1 & 2.03 & Sandy silt \\
\hline 4 & 80 & 4.773 & 5.09 & 1.18 & 0.58 & 2.11 & 3.88 & 90.26 & 4.74 & Silt \\
\hline 5 & 150 & 4.817 & 5.1 & 1.16 & 0.57 & 2.37 & 1.4 & 94.38 & 4.22 & Silt \\
\hline 6 & 180 & 4.329 & 3.7 & 2.03 & -0.45 & 2.16 & 25.88 & 65.38 & 2.82 & Sandy silt \\
\hline 7 & 200 & 4.781 & 5.06 & 0.94 & 0.56 & 2.21 & 1.24 & 96.12 & 2.44 & Silt \\
\hline 8 & 100 & 2.401 & 2.07 & 2.24 & -0.14 & 1 & 68.92 & 21.75 & 1.41 & Silty sand \\
\hline 9 & 150 & 2.629 & 2.27 & 2.33 & -0.17 & 1.07 & 56.96 & 29.48 & 1.64 & Silty sand \\
\hline 10 & 150 & 1.498 & 1.56 & 2.62 & 0.14 & 0.79 & 57.04 & 19.39 & 1.81 & Silty sand \\
\hline 11 & 100 & 3.833 & 3.82 & 1.1 & 0.02 & 1.74 & 57.96 & 37.58 & 2.46 & Silty sand \\
\hline 12 & 150 & 4.657 & 3.97 & 2.15 & -0.44 & 2.23 & 23.6 & 69.13 & 3.47 & Sandy silt \\
\hline 13 & 150 & 2.858 & 2.26 & 2.76 & -0.16 & 0.76 & 43.72 & 38 & 1.84 & Silty sand \\
\hline 14 & 130 & -0.473 & -0.15 & 1.32 & 0.42 & 0.97 & 69.56 & 3.56 & 0.2 & Silty sand \\
\hline 15 & 150 & 4.415 & 3.71 & 1.66 & -0.59 & 1.2 & 35.32 & 63.28 & 1.04 & Sandy silt \\
\hline 16 & 180 & 2.54 & 2.2 & 2.4 & -0.1 & 0.95 & 64.92 & 24.29 & 2.03 & Silty sand \\
\hline 17 & 120 & 2.765 & 2.46 & 2.37 & -0.11 & 1.04 & 56 & 34.94 & 1.82 & Silty sand \\
\hline
\end{tabular}


Orabi, et al

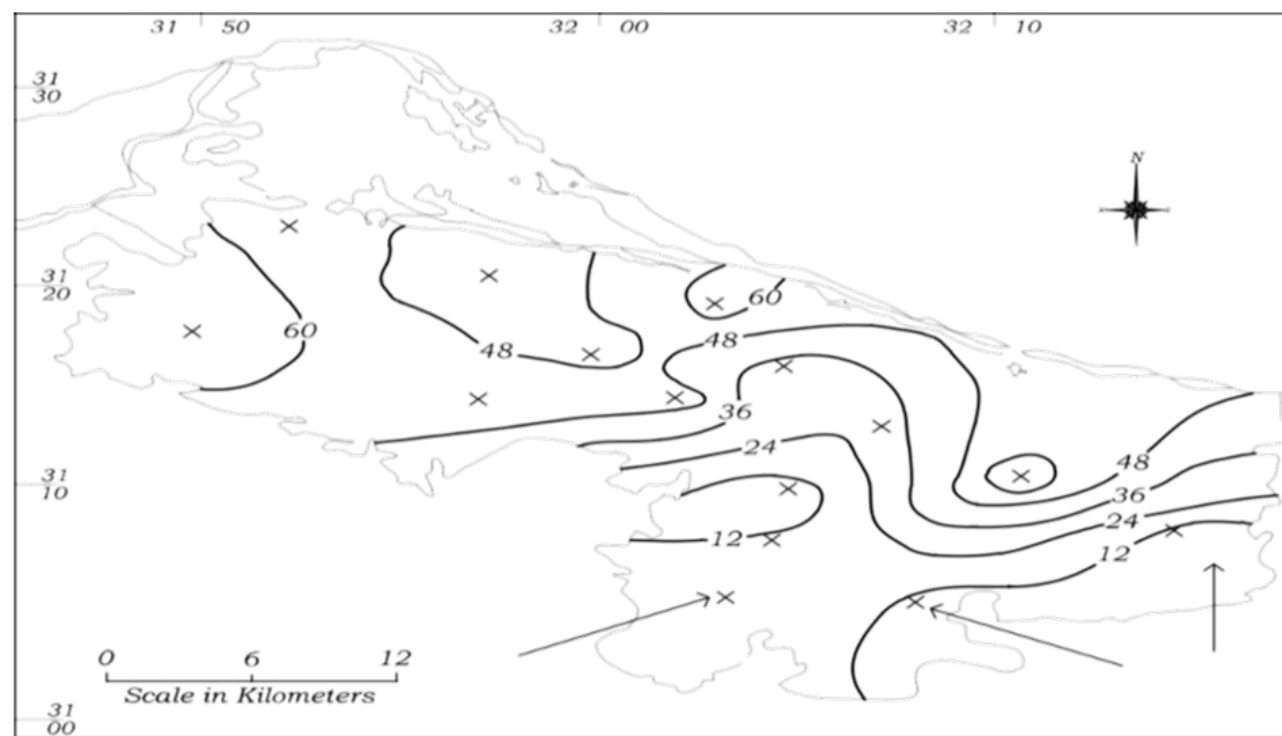

Fig. 2. The distribution of sand $\%$ in the Manzala Lake.

Fig. 3. The distribution of silt $\%$ in the Manzala Lake.
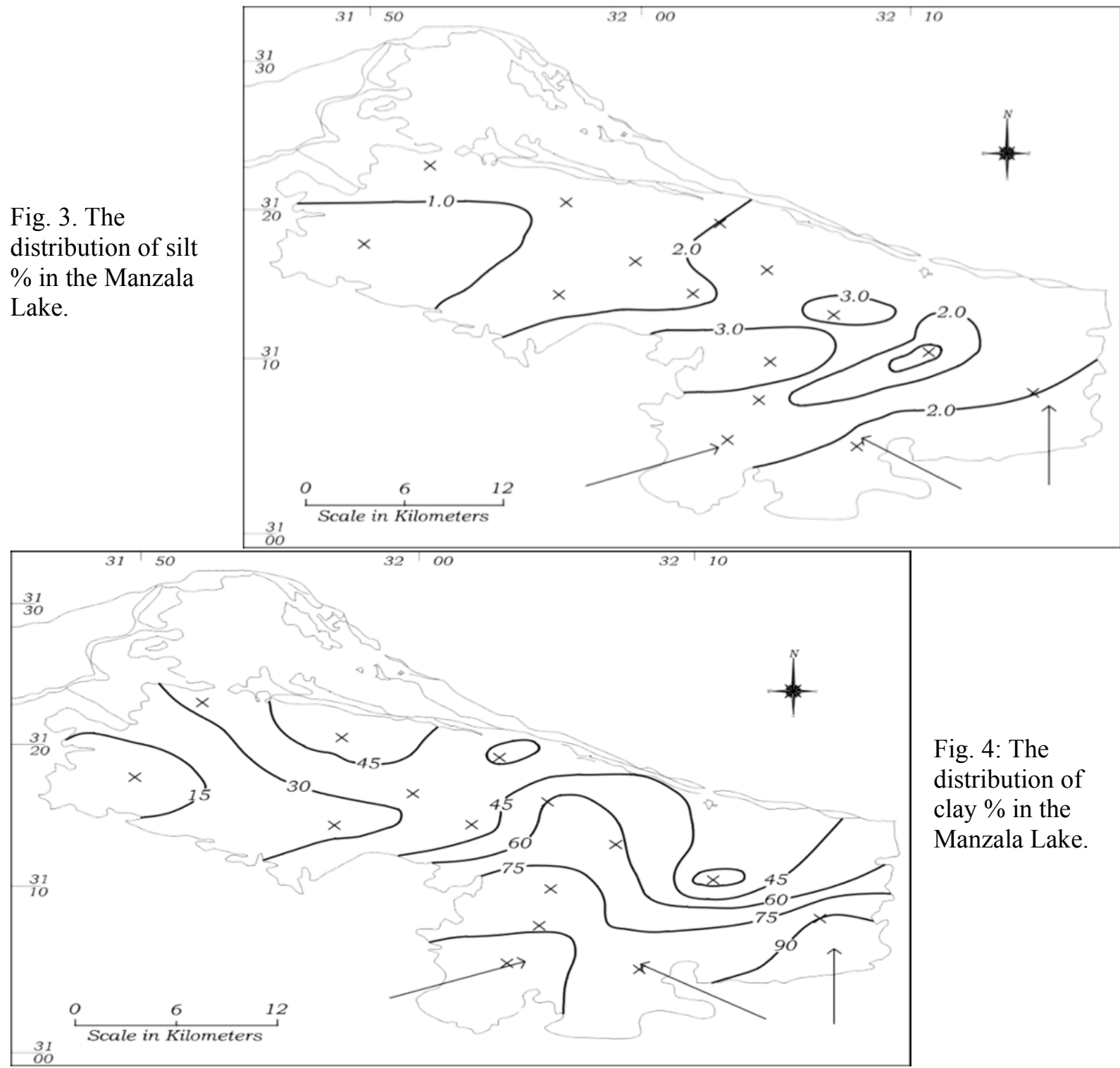

Fig. 4: The distribution of clay $\%$ in the Manzala Lake. 


\section{Physical and Chemical Properties}

\section{Water temperature}

Due to the shallowness of Lake Manzala together with the common mixing of water by wind, the thermal stratification was difficult to be established in the water body of the lake (Wahby et al., 1972).

Temperature is an important parameter in the environment of deposition. It affects the solubility of carbon dioxide and precipitation of calcium carbonate. It also affects the flourishing of the water flora and bottom fauna. The bottom water temperature in the lake fluctuates between minimum of $15^{\circ} \mathrm{C}$ in January/February to maximum of $33.5^{\circ} \mathrm{C}$ in July. During summer season, the temperature at the bottom fluctuated between $29.5^{\circ} \mathrm{C}$ to $33.5^{\circ} \mathrm{C}$ with an average $32^{\circ} \mathrm{C}$ (Fig. 5).

Fig. 5.

Distribution of water temperature in the Manzala Lake.

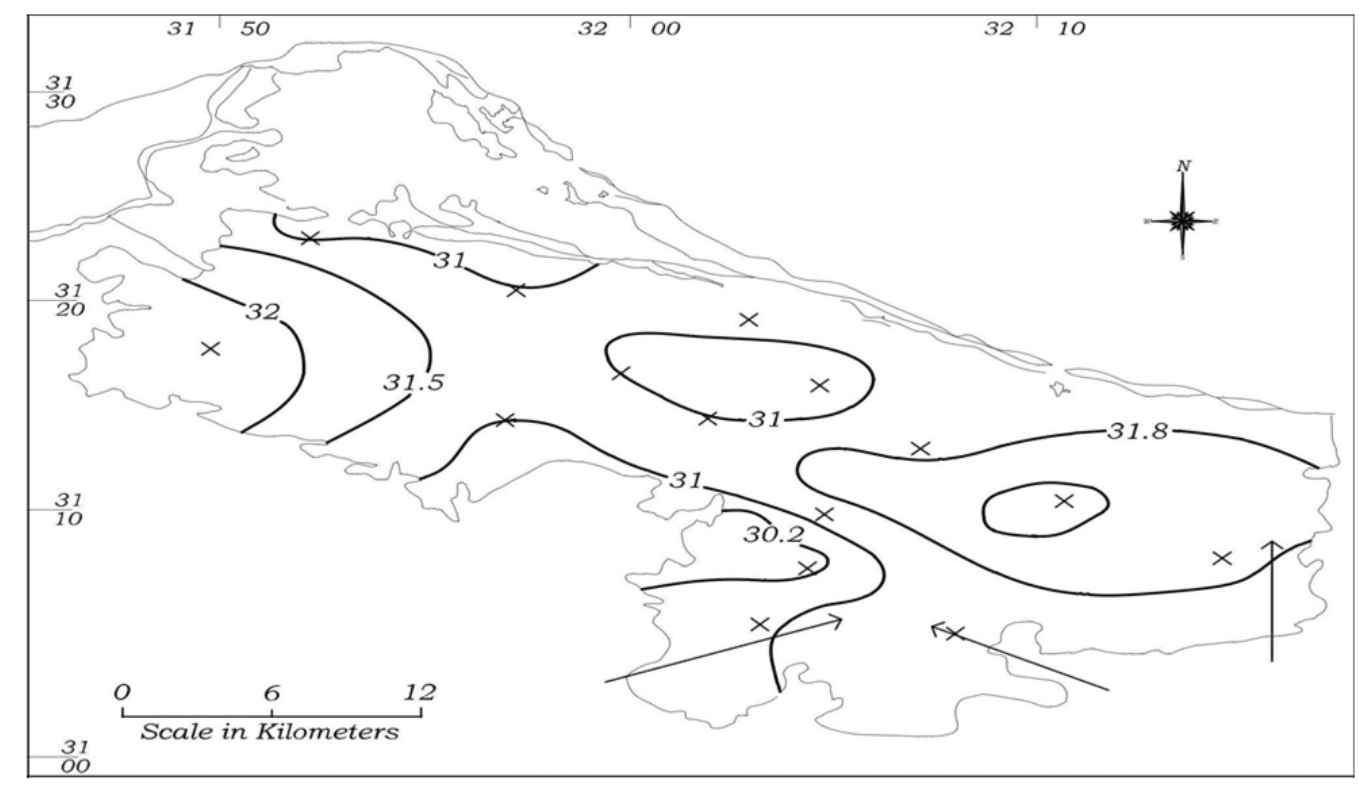

\section{Transparency}

Transparency can be considered as an indicator for the percentage of light penetrating through the water. It is known that the water transparency is generally low at the Manzala Lake. This may be attributed to the shallowness and the continuous disturbance of the mud bottom by wind action (Shakweer, 2005). It was observed that the lowest transparency depth $(56.7 \mathrm{~cm})$ during January. On the other hand, the highest transparency $(75.7 \mathrm{~cm})$ was recorded in the area near El Bough connection during November.

The maximum transparency of the water is represented the northwestern region from the lake, while the minimum transparency is recorded in the eastern south part (Fig. 6).

\section{Hydrogen Ion Concentration (pH)}

The hydrogen ion plays an important role in many of the life processes and living organisms in the aquatic environment. Measurement of $\mathrm{pH}$ in the aquatic habitat is essential as it reflects the biological activity and changes in the water as well as the extent of water pollution.

The $\mathrm{pH}$ values of Manzala Lake fluctuates around 8.82 to 7.55 in the northern sector, which are relatively high. The $\mathrm{pH}$ values of the southern stations are lower, perhaps due to fermentation of the organic matter which enriches these stations and to low oxygen (Fig. 7).

The distribution of the $\mathrm{pH}$ values during summer season reveal that the water mass in Manzala Lake tend to be slightly alkaline, Station 1 and 5 showed almost the lowest $\mathrm{pH}$ value (7.55) this could be attributed either to low primary productivity. On the other hand station 14 in the western side of the lagoon showed the highest $\mathrm{pH}$ value (8.82), which may be attributed to the greatest light penetration of the water at this station. This penetration enhances the photosynthetic activity. 


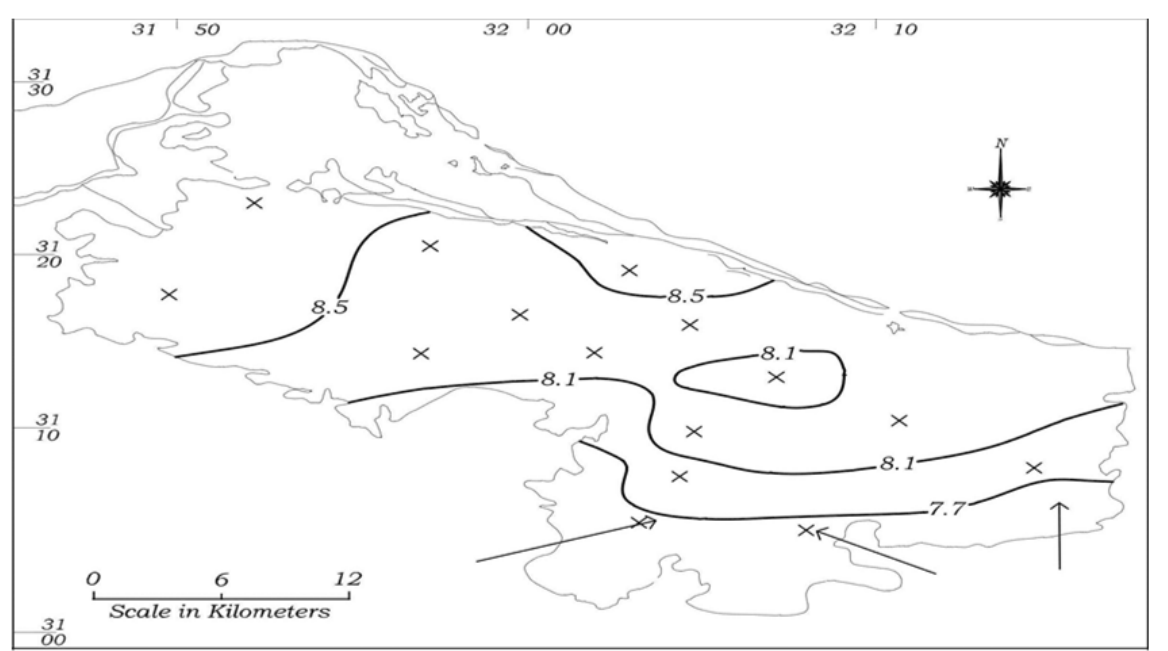

Fig. 6: Distribution of water transparency in the Manzala Lake.

Fig. 7: The distribution of hydrogen ion concentration $(\mathrm{pH})$ in the Manzala Lake.

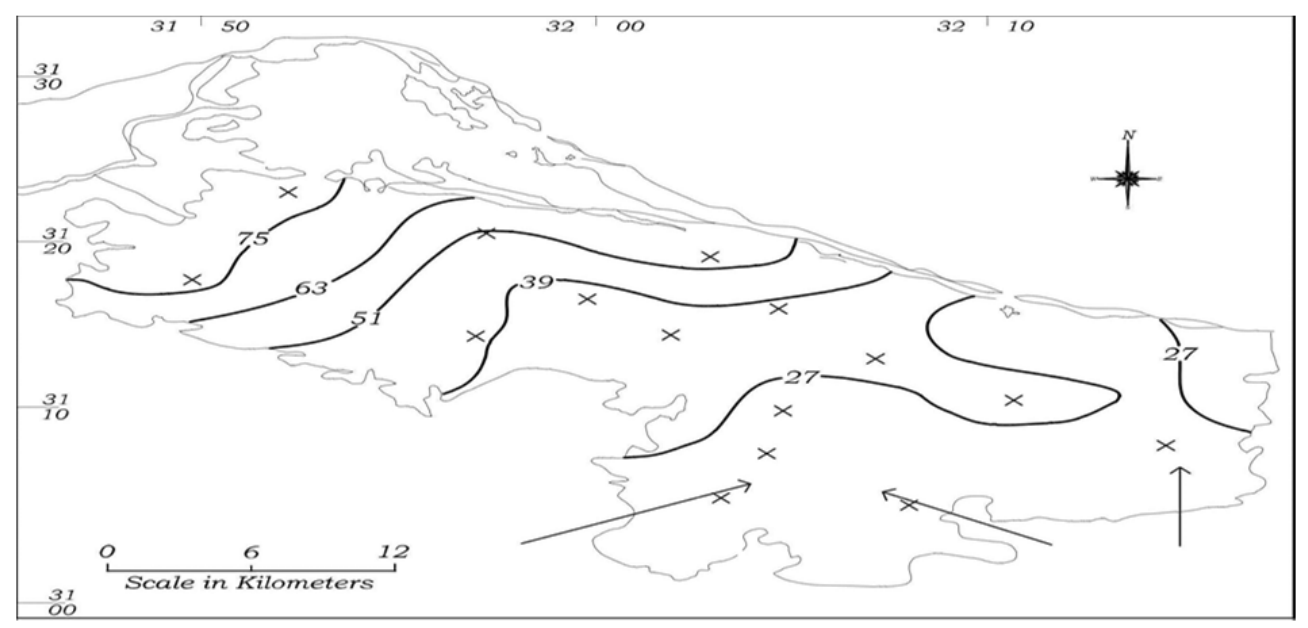

\section{Water Conductivity}

During summer season, the distributions of conductivity at the bottom are shown in figure 8 . The bottom conductivity values are varies between $2400 \mu \mathrm{mohs} / \mathrm{cm}$ to $17690 \mu \mathrm{mohs} / \mathrm{cm}$ with an average $7194 \mu \mathrm{mohs} / \mathrm{cm}$. The low value of conductivity was observed at the western part. This agrees with what was obtained from chlorosity values.

Generally, the conductivity value increase towards opening of Boughas El-Gamil (Northern part of the lagoon and agree with chlorosity value (i.e. conductivity value is considered as function of chlorosity).

\section{Water Salinity}

Both Electrical conductivity and salinity values are distributed in the Manzala Lake in a similar trend. Their values increased in the north eastern area near to Boughaz El-Gamil recording the maximal values of (43.8 mS/cm and $22.5 \%$ respectively) (Khalil and Bayoumi, 1988 and Abd El-Satar, 2001.

The Manzala Lake is a brackish lake because of its connections with the Mediterranean Sea. The lake sustains a mixture of marine and freshwater fish (Bishai and Youssef, 1977). The lake water is generally brackish, ranging in salinity from a low of $2 \%$ in the western and southern regions to $16-23 \%$ in the southeast and near the outlets at the north (Zalat and Vildary, 2005). The salinity showed remarkable variation between $14 \% \mathrm{o}$ and $32 \% \mathrm{o}$ in winter and summer respectively (Madkour and El-Shoubaky, 2007) to $21.5 \%$ (Ali, 2008). El-Morsi et al. (2017) recorded the salinity and ranging from $19.8 \mathrm{~g} / \mathrm{L}$ to $1.10 \mathrm{~g} / \mathrm{L}$.

This declining pattern is attributed to an increase in inflow of agricultural drainage water and the restriction of water inflow in the Gamil Lake-Sea connection. 
Chemical-physical and ecological characterisation

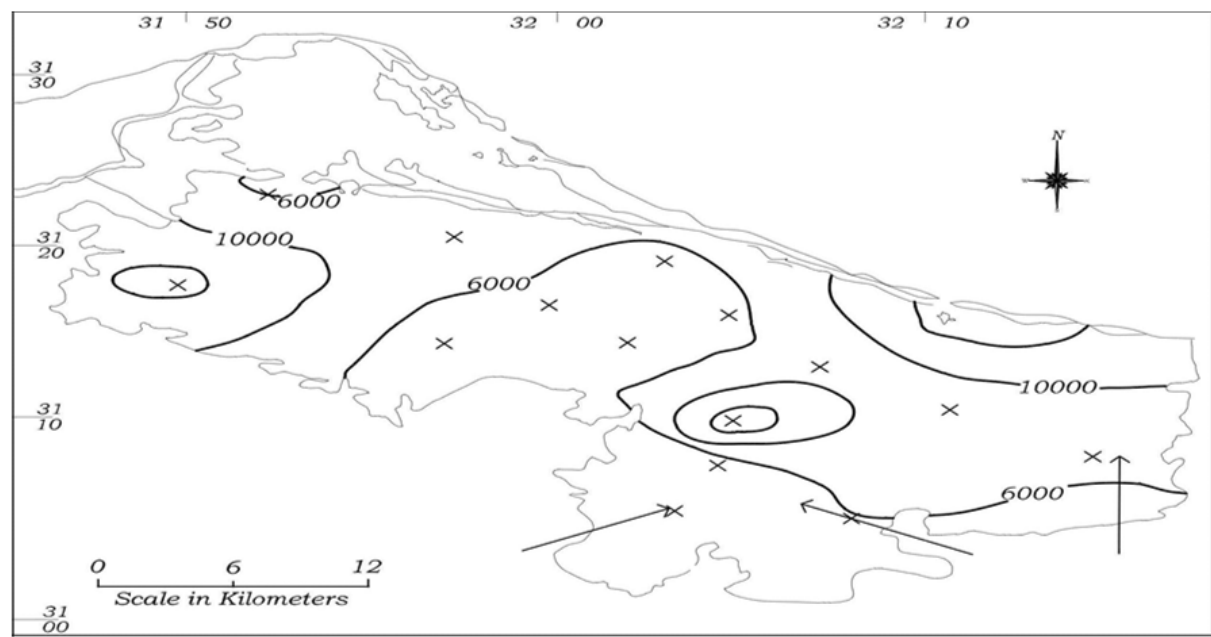

Fig. 8: The distribution of bottom water conductivity $(\mu \mathrm{mhos} / \mathrm{cm})$ in the Manzala Lake.

\section{Water Chloroisty}

Chlorosity was measured at each station for bottom water by ergonometric method as recommended in American Public Health Association (APHA, 1998). The concentration of chlorosity in the lake are governed by the drainage water input mainly from Bahr El-Baqar and Hadous drains, which affect principally the water of the south-eastern region of the lake. Water chloroisty also affected by mixing of lake water through the lake-sea connection due to water movement into or out from the lake, which depending on the wind condition, temperature variation and water levels between the sea and the lake proper.

The chlorosity gradient increases toward the opening of Boughas El-Gamil, where the distribution map (Fig. 9) shows there is an increase toward the inlet. The chlorosity varied from $425 \mathrm{mg} / \mathrm{L}$ to $4034 \mathrm{mg} / \mathrm{L}$, with an average $(1719 \mathrm{mg} / \mathrm{L})$ and increase north ward.

Fig. 9: The distribution of bottom water chlorosity $(\mathrm{mg} / \mathrm{L})$ in the Manzala Lake.

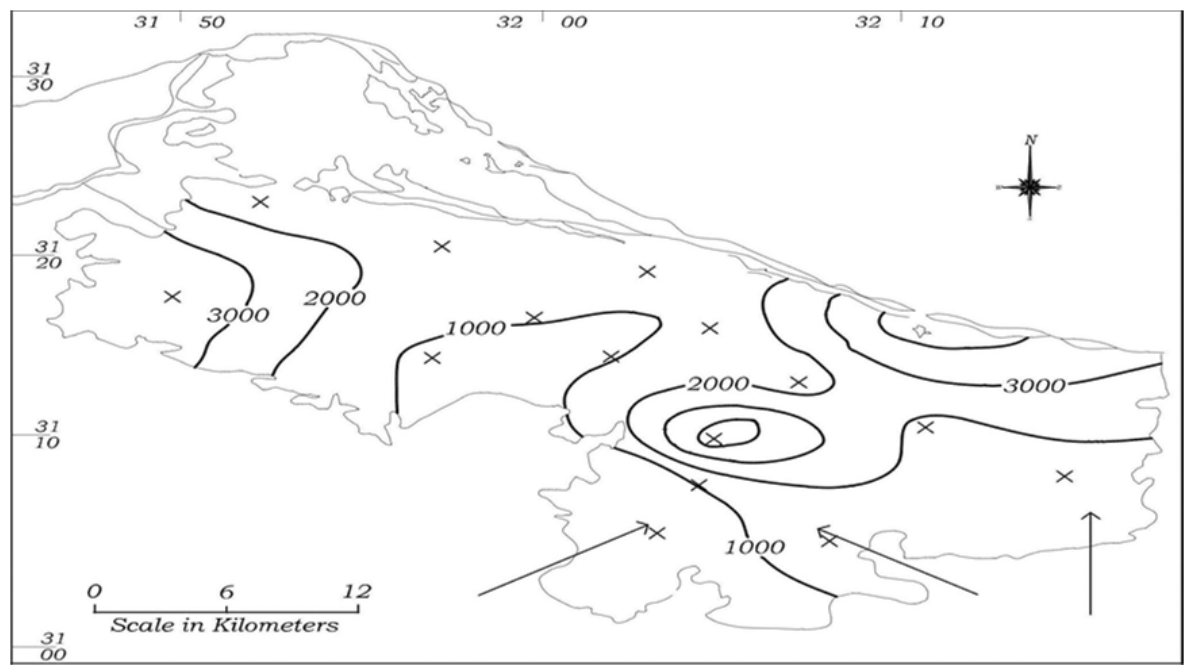

HEAVY METALS ENVIRONMENTAL STATUS

The following is a brief discussion on the environmental status of some metals in bottom sediments that may bear some risk or endanger on human environment.

Lead $\mathbf{( P b}$ ) among all metals; $\mathrm{Pb}, \mathrm{Cd}$ and $\mathrm{Zn}$ are in the closest relationship to humans; however, $\mathrm{Pb}$ is damaging to the human body. In the present work, the total lead content ranges from 19.6 to $153.6 \mathrm{ppm}$, with an average of $78.48 \mathrm{ppm}$. The lowest value is recorded at middle portion of the lake while the highest values are recorded near El-Serw agricultural drain and also, at eastern portion of the lake where the industrial region in Port Said country. 


\section{Orabi, et al}

The MPL of $\mathrm{Pb}$ in the worldwide soils is $20 \mathrm{ppm}$. According to the Agency for Toxic Substances and Disease Registry, soil contamination by lead from mine tailings may be less effective in increasing PbB (blood lead) levels than its lead contamination derived from urban lead pollution.

Cadmium (Cd) it is more mobile in aquatic environments than most other heavy metals. According to Kabata-Pendias (1995), the Maximum Permissible Limit (MPL) of Cd in cultivated soil is $0.5 \mathrm{ppm}$. The Department of Health and Human Services (DHHS) has determined cadmium and cadmium compounds as carcinogens; therefore, the Environmental Protection Agency (EPA) has set a limit of $5 \mathrm{ppm}$ of cadmium for drinking water. In the present study, the $\mathrm{Cd}$ content ranges from 5.9 to $22.3 \mathrm{ppm}$ with an average value of $17.5 \mathrm{ppm}$. Therefore, the average content of $\mathrm{Cd}$ in the study area is more than 36 fold the MPL of soil as quoted by Kabata-Pendias (1995). While the highest Cd content (22.3 ppm) is more than 48 fold. Generally, $\mathrm{Cd}$ can be a serious pollutant for the lake bottom sediments. It is mostly related to phosphate fertilizers at El-Serw agriculture drain, also possible source where $\mathrm{Cd}$ is the combustion of fossil fuel and some industrial activities at western portion of the studied lake.

Cobalt (Co) its content ranges between 71 and $164 \mathrm{ppm}$ in lake sediments, averaging $110 \mathrm{ppm}$. This average value is more than two fold of the MPL recorded for the worldwide soil (50 ppm) as quoted by Kabata-Pendias (1995). The content of Co increases toward the eastern side of the studied lake due to industrial activities in Port Said country. Other focused of pollution has been distinguished near El-Serw agricultural drain (Ghallb, 2007).

Copper (Cu), its content ranges from 2.9 to $86.5 \mathrm{ppm}$, averaging $19.7 \mathrm{ppm}$. The highest content is almost equal to the MPL (100 ppm) according to Kabata-Pendias (1995). It was noticed that $\mathrm{Cu}$ content increases gradually toward the south eastern portion of the lake due to Bahr el Baqar drain, with several anomalous patches near the main cities and close to Damietta country, which seems to be the main industrially polluted (Kabata-Pendias et al., 1992; Mason and Moore, 1982).

Zinc (Zn) its content in the studied lake ranges between 65.1 and $461.8 \mathrm{ppm}$, averaging $130 \mathrm{ppm}$. The content increases toward south eastern portion, due to industrial activity in Port Said country.

Nickel (Ni) considered as a very toxic element. In the present study, Ni content ranges between 117 and $302 \mathrm{ppm}$, averaging $228 \mathrm{ppm}$. This average value is more than two fold the MPL recorded for the worldwide soil (100 ppm), as quoted by Kabata-Pendias (1995). Ni is concentrated at the eastern part of the lake due to industrial activity near Port Said. Fe also accumulates at the northwestern side of the studied area, close to El Serw drain and the industrial region of Damietta (El-Kammar et al., 2009).

Iron (Fe) in the present study content ranges between $6218 \mathrm{ppm}$ and $14130 \mathrm{ppm}$, averaging 10800 ppm. Fe content is concentrated at southeastern portion of the lake towards Bahr El Baqar drain, also Fe accumulated at northwestern side where the Damietta industrial region (Salomons and Forstner, 1984).

\section{The Regional Pollution Index (RPI)}

The degree of pollution of the Manzala Lake bottom sediments can be calculated by normalizing the metals concentration to their Maximum Permissible Limits (MPL) used for the worldwide soil. In the given equation of the pollution index, the MPL of an element is considered as the "pollution standard level or goal". The index of an individual pollutant is calculated as follows:

$$
\begin{aligned}
& \text { Pollutant standard level } \\
& \text { Index }=\text { - }-\mathbf{- - -} \text { Pollutant standard level or goal }
\end{aligned}
$$

For each region, the highest calculated index is used as the RPI for that region. An RPI of 50 corresponds to the relevant standard/goal. The RPI is categorized as low, medium or high, as follows:

Low pollution index from 0 to 24

Medium pollution index from 25 to 49

High pollution index 50 or higher. 


\section{Chemical-physical and ecological characterisation}

The RPI of the studied Manzala Lake bottom sediments summarizes in table 2, where the studied area is exposed to high pollution levels by $\mathrm{Cd}, \mathrm{Pb}, \mathrm{Ni}$ and $\mathrm{Co}$. Meanwhile, $\mathrm{Zn}$ and $\mathrm{Cu}$ display low degree of pollution (Table 2).

Table 2: Average heavy metals of the Manzala Lake compared to the average of the Maximum Permissible Limit (MPL) in the worldwide soils Kabata-Pendias (1995) and Regional Pollution Index (RPI).

\begin{tabular}{|c|c|c|c|c|}
\hline Elements & Manzala Lake $(\mathrm{ppm})$ & MPL $(\mathrm{ppm})$ & RPI & Type of pollution \\
\hline $\mathrm{Cd}$ & 18 & 0.5 & 1754 & High \\
\hline $\mathrm{Cu}$ & 20 & 100 & 10 & Low \\
\hline $\mathrm{Ni}$ & 228 & 100 & 114 & High \\
\hline $\mathrm{Co}$ & 110 & 50 & 110 & How \\
\hline $\mathrm{Zn}$ & 130 & 300 & 22 & High \\
\hline $\mathrm{Pb}$ & 78 & 20 & 196 & \\
\hline
\end{tabular}

\section{BIO-INDICATOR}

Schistosomiasis is one of the most widespread of all human parasitic diseases, ranking second only to malaria in terms of its socioeconomic and public health importance in tropical and subtropical areas. It is also the most prevalent of the waterborne diseases and one of the greatest risks to health in rural areas of developing countries.

As a mainly rural, often occupational disease, schistosomiasis principally affects people who are unable to avoid contact with water, either because of their profession (agriculture, fishing) or because of a lack of a reliable source of safe water for drinking, washing and bathing. As a result of a low level of resistance and intensive water contact when playing and swimming, children aged between 10 and 15 years are the most heavily infected. Increased population movements help to spread the disease and schistosomiasis is now occurring increasingly in periurban areas.

\section{Molluscan Study}

A total of 13 species belonging to 8 families under class gastropod (11 genera) were collected from the sites of investigation during the study periods at Manzala Lake. Several factors are considered as affecting the ecology of snails and other intermediate hosts of diseases, hence their focal and seasonal distributions.

Freshwater mollusca have been known to play significant roles in the public and veterinary health and thus need to be scientifically exploring more extensively (Supian and Ikhwanuddin, 2002). About 7 species of freshwater gastropods are reported to act as intermediate hosts for the diagnostic trematode parasites and among Prosobranchs, members of the family Pilidae and Thiaridae were recorded to harbor larval trematodes (Subba-Rao, 1993). The gastropods Bulinus (Bulinus) truncatus, Bellamya unicolor, Biomphalaria alexandrina, B. glabrata, B. pfeifferi, Melanoides tuberculata and Lymnaea columella are of considerable importance because they can act as a host for Cercaria pusilla, Fasciola hepatica, Schistosoma mansoni and Schistosoma haematobium disease vectors. The latter two can cause Schistosomiasis transmission (Bilharzia). Their distribution is a mostly restricted to the relatively freshwater southern and western sectors of the Manzala Lake (Orabi and Osman 2015). Meanwhile only one genus of saline water was recorded at the area of study (Cerithium).

Many studies concerned with the ecology and population dynamics of gastropods which play an important role in transmitting diseases to man and his livestock have been conducted by Abd El-Malek (1958); Dazo et al. (1966); Barbosa and Barbosa (1994); Utzinger et al. (1997); Kloos et al. (2001); Karimi et al. (2004); Cañete et al. (2004), Kazibwe et al. (2006) and Mostafa, (2009).

Population dynamics of gastropods depend on the physical geography of a given region, also land contours, soil composition; hydrography and climate all have effect on snail population dynamics (ElKhayat et al., 2011). The snail species were identified and illustrated in Plate 1.

\section{Foraminifera Study}

Effects of anthropogenic impacts on benthic foraminiferal included foraminiferal diversity, density or assemblages and even morphological abnormalities have been observed in different lakes with heavy 
Orabi, et al

metals pollution or eutrophication (e.g., Alve, 1995; Yanko et al., 1999; Luciani, 2007; Armynot du Châtelet and Debenay, 2010; Buosi et al., 2010; Frontalini and Coccioni, 2011; Orabi et al., 2017).

\section{Test morphology and abnormality of Ammonia tepida}

Ammonia tepida is the most dominant species in the lake. It covers more than $97 \%$ of the total benthic foraminiferal assemblages (Table 3). The highest value of total dissolved salts was recorded in the eastern portion of the lake near the El-Boughaz opening $(17.56 \mathrm{mg} / \mathrm{L})$ as it is affected by sea water. This value decreases to its lowest value of $0.995 \mathrm{mg} / \mathrm{L}$ in the middle sector with an average of $4.47 \mathrm{mg} / \mathrm{L}$., reflecting this species tolerance to very low salinity and making it the most widely distributed in the Manzala Lake.

Table 3: Shows the species counting and deformed tests in the fine fraction $63 \mu \mathrm{m}(\Phi 4)$.

\begin{tabular}{|c|c|c|c|c|c|c|c|c|c|}
\hline \multirow{2}{*}{$\begin{array}{c}\text { Station } \\
\text { No. }\end{array}$} & $\begin{array}{c}\text { Ammonia } \\
\text { tepida }\end{array}$ & $\begin{array}{c}\text { Elphidium } \\
\text { excavatum }\end{array}$ & $\begin{array}{c}\text { Adelosina } \\
\text { Miliolids } \\
\text { spp. }\end{array}$ & $\begin{array}{c}\text { Quinq. } \\
\text { seminula }\end{array}$ & $\begin{array}{c}\text { Triloculina } \\
\text { trigonula }\end{array}$ & $\begin{array}{c}\text { Rosalina } \\
\text { bradyi }\end{array}$ & Total & $\begin{array}{c}\text { Deformed } \\
\text { Deformed } \\
\%\end{array}$ \\
\hline 1 & 90 & 0 & 0 & 0 & 0 & 0 & 90 & 11 & $11 \%$ \\
\hline 2 & 94 & 6 & 0 & 0 & 0 & 0 & 94 & 13 & $13 \%$ \\
\hline 3 & 90 & 0 & 0 & 0 & 0 & 0 & 90 & 7 & $7 \%$ \\
\hline 4 & 85 & 9 & 0 & 3 & 3 & 0 & 100 & 8 & $8 \%$ \\
\hline 5 & 93 & 0 & 0 & 0 & 4 & 3 & 100 & 6 & $6 \%$ \\
\hline 6 & 97 & 3 & 0 & 0 & 0 & 0 & 100 & 7 & $7 \%$ \\
\hline 7 & 96 & 4 & 0 & 0 & 0 & 0 & 100 & 9 & $9 \%$ \\
\hline 8 & 83 & 7 & 0 & 0 & 0 & 0 & 83 & 0 & 0 \\
\hline 9 & 94 & 6 & 0 & 0 & 0 & 0 & 100 & 8 & $8 \%$ \\
\hline 10 & 93 & 7 & 0 & 0 & 0 & 0 & 100 & 6 & $6 \%$ \\
\hline 11 & 91 & 9 & 0 & 0 & 0 & 0 & 100 & 0 & 0 \\
\hline 12 & 87 & 8 & 0 & 5 & 0 & 0 & 87 & 5 & $5 \%$ \\
\hline 13 & 90 & 6 & 0 & 0 & 0 & 0 & 90 & 0 & 0 \\
\hline 14 & 100 & 0 & 0 & 0 & 0 & 0 & 100 & 0 & 0 \\
\hline 15 & 100 & 0 & 0 & 0 & 0 & 0 & 100 & 8 & $8 \%$ \\
\hline 16 & 100 & 0 & 0 & 0 & 0 & 0 & 100 & 4 & $4 \%$ \\
\hline 17 & 87 & 4 & 0 & 0 & 0 & 0 & 91 & 9 & $9 \%$ \\
\hline
\end{tabular}

Ammonia tepida exhibits a great morphological variability (Plate 2). The recorded morphological abnormalities show aberrant chamber shape (Plate 2, No.1, 7 and 8), Ammonia tepida exhibits aberrant chamber shape and size and irregular rather than lobulated periphery (Plate 2, No.7). Adelosina sp., show aberrant chamber shape and size (Plate 2, No. 1) and Miliolids spp., show complex deformities (Plate 2, No. 2), whereas Elphidium excavatum show aberrant chamber shape and size (Plate 2, No. 6, 7, 8). 
Chemical-physical and ecological characterisation

\section{Plate 1}

Scale bar for all specimens $=10 \mathrm{~mm}$.

1- Biomphalaria glabrata (Say, 1818).

2- Melanoides tuberculata (Müller, 1774)

3- Bulinus (Isidora) truncatus (Audouin, 1827).

4- Lymnaea columella (Say, 1817).

5- Theodoxus (Neritaea) anatolicus (Rècluz, 1841)

6- Hydrobia acuta (Draparnaud, 1805).

7- Lymnaea (Galba) truncatula (Müller, 1774).

8- Planorbis planorbis (Linnaeus, 1758).

9- Viviparus contectus (Millet, 1813).

10- Biomphalaria pferifferi (Krauss, 1848).

11-Cerithium scabridum (Philippi, 1849).

12-Bellamya unicolor (Olivier, 1804).

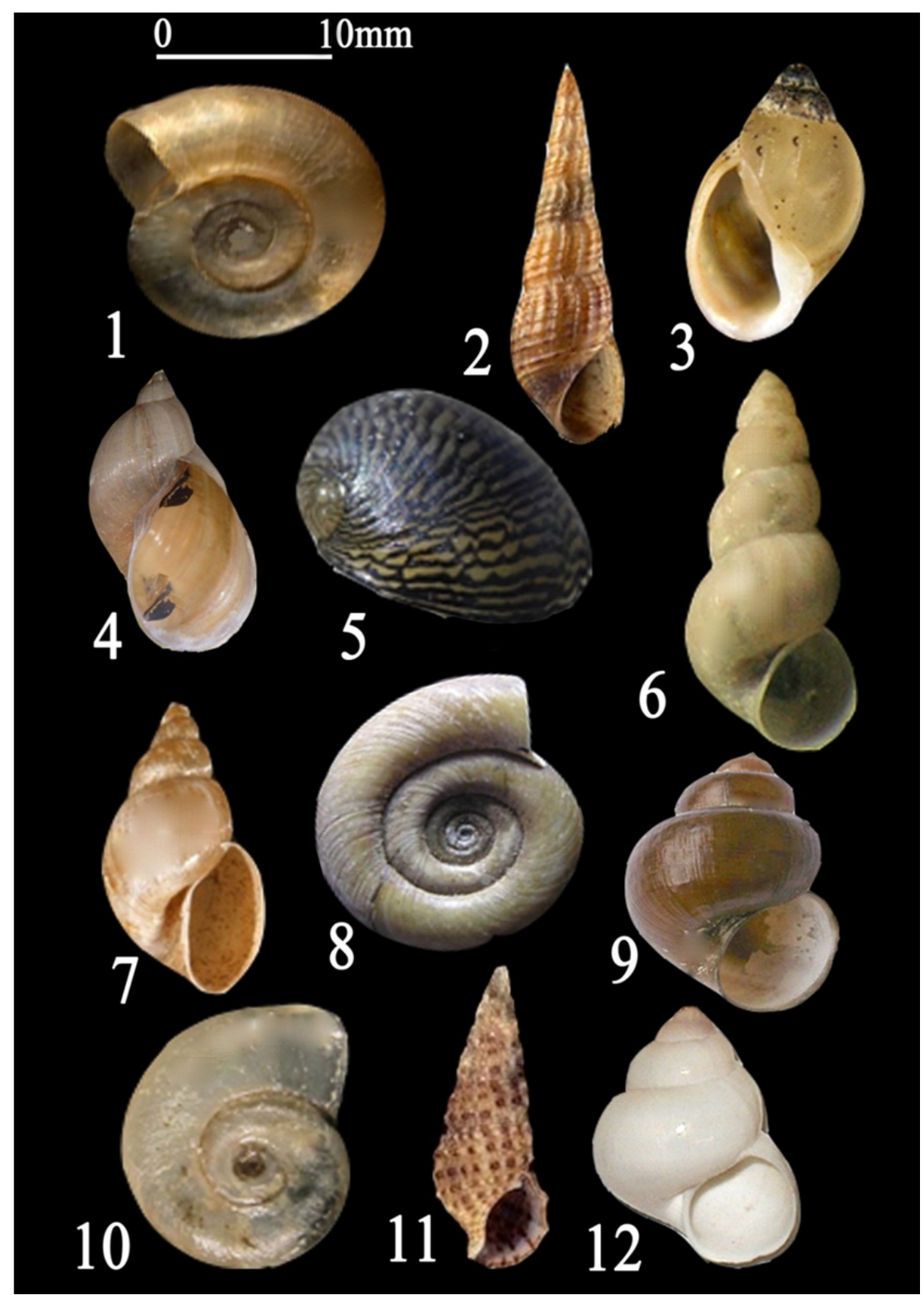


Orabi, et al

Plate 2

1. Adelosina sp., aberrant chamber shape (Station 7).

2. Miliolids sp., complex deformities (Station 7).

3. Quinqueloculina seminulum (Linnaeus), side views (Station 4).

4. Triloculina trigonula (Lamarck), side view (Station 4).

5. Ammonia tepida (Cushman) no deformed, 5a- dorsal view, 5b- ventral view (Station 7).

6. Elphidium excavatum (Terquem), side view (Station 7), no deformed.

7. Elphidium excavatum (Terquem), aberrant chamber shape and size (Stations 2).

8. Elphidium excavatum (Terquem), aberrant chamber shape and size (Stations 4).

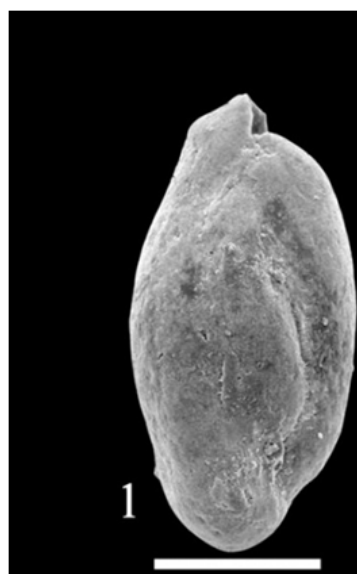

$\mathbf{5 0} \mu \mathrm{m}$

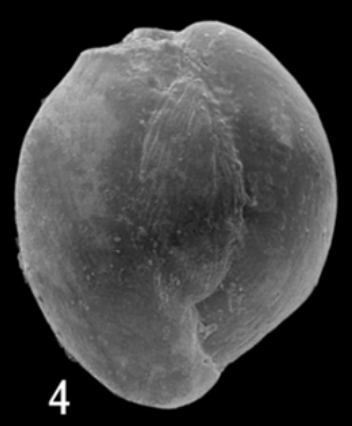

$50 \mu \mathrm{m}$

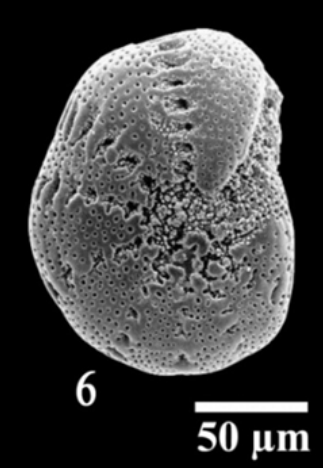

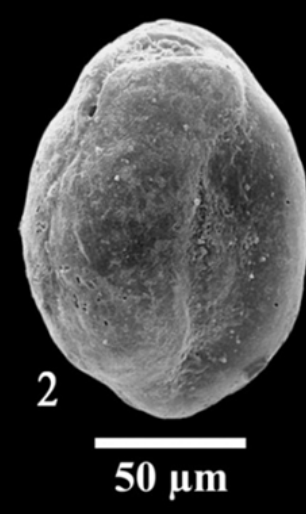
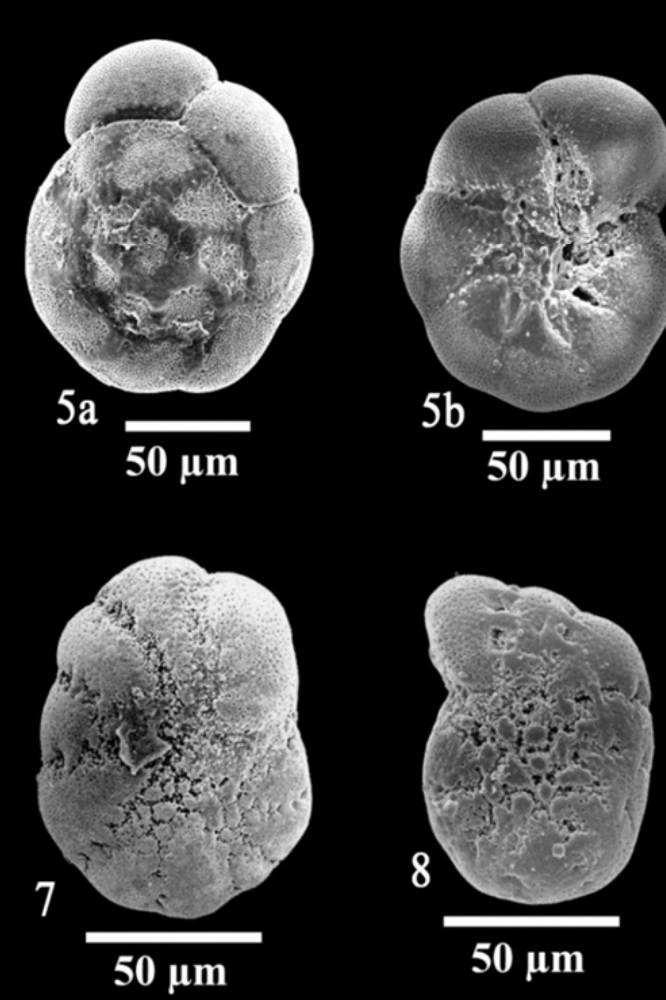


\section{Chemical-physical and ecological characterisation}

\section{SUMMARY AND CONCLUSION}

1. The sand distribution map of the whole area is characterized by relatively coarser fractions (silty sand) and located at the western part of the lake. The sediment distribution map of silt fraction reveals that the medium fraction (silt type) was located at the eastern part of the lake. Meanwhile, the sediment distribution map of clay fraction reveals that the fine fraction (clay type) was located at the western part of the lake.

2. Physical and chemical properties reveal that the water transparency is low at the Manzala Lake. This may be attributed to the shallowness and the continuous disturbance of the mud bottom by wind action. On the other hand, the highest transparency $(75.7 \mathrm{~cm})$ was recorded in the area near El Bough connection, where the distribution of the $\mathrm{pH}$ values during summer season reveal that the water mass in Manzala Lake tend to be slightly alkaline. The salinity values increased in the north eastern area near to Boughaz El-Gamil, The lake water is generally brackish, ranging in salinity from a low of $2 \%$ in the western and southern regions to $16-23 \%$ in the southeast and near the outlets at the north.

3. The studied area is exposed to high pollution levels by $\mathrm{Cd}, \mathrm{Pb}, \mathrm{Ni}$ and $\mathrm{Co}$. Meanwhile, $\mathrm{Zn}$ and $\mathrm{Cu}$ display low degree of pollution. The highest values of heavy metals are recorded near El-Serw agricultural drain and also, at eastern portion of the lake near Bahr El-Baqar agricultural drain where the industrial region in Port Said country.

4. About 7 species of freshwater gastropods are reported to act as intermediate hosts for the diagnostic trematode parasites and among Prosobranchs, members of the family Pilidae and Thiaridae were recorded to harbor larval trematodes.

5. Ammonia tepida is the most dominant species in the lake. It covers more than $97 \%$ of the total benthic foraminiferal assemblages, and exhibits a great morphological variability. The recorded morphological abnormalities show aberrant chamber shape.

\section{REFERENCES}

Abd El Satar, A. M. (2001): Environmental studies on the impact of the drains effluent upon the southern sector of Lake Manzala, Egypt, Egypt. J. Aquat. Biol. and Fish., 5(3): 17- 30.

Abd El-Malek, E. 1958): Factors conditioning the habitat of Bilharziasis intermediate hosts of the family Planorbidae. Bull. Org. mond. Santé. Bull. Wld. Hlth. Org., 18: 785-818.

Ali, M. H. H. (2008): Assessment of some water quality characteristics and determination of some heavy metals in Lake Manzala, Egypt. Egypt. J. Aquat. Biol. \& Fish., 12(2): 133 -154.

Alve, E., (1995): Benthic foraminiferal response to estuarine pollution: a review. Journal of Foraminiferal Research 25, 190-203.

APHA. (1998): Standard Methods for Examination of Water and Wastewater, American Public Health Association Inc. Washington DC. $20^{\text {th }}$ ed., USA.

Armynot du Châtelet, E. and Debenay, J.P., (2010): Anthropogenic impact on the western French coast as revealed by foraminifera: a review: Revue de Micropaléontologie, 53, 129-137.

Barbosa, F. S. and Barbosa, C. S. (1994): The bioecology of snail vector for Schistosomiasis in Brazil. Cad. Saùde Pùbl., Rio de Janeiro, 10 (2): 200-209.

Buosi, C., Frontalini, F., Da Pelo, S., Chechi, A., Coccioni, R., Bucci, C., (2010): Foraminiferal proxies for environmental monitoring in the polluted lagoon of Santa Gilla (Cagliari, Italy): Present Environment and Sustainable Development, 4, 91-103.

Cañete R, Yong M, Sánchez J, Wong L, Gutiérrez A (2004): Population dynamics of intermediate snail hosts of Fasciola hepatica and some environmental factors in San Juan y Martinez municipality, Cuba. Mem Inst Oswaldo Cruz 99: 257-262.

Dazo, B. C., Hairston, N. G. and Dawood, I. K. (1966): The ecology of Bulinus truncatus and Biomphalaria alexandrina and its implications for the control of Bilharziasis in the Egypt- 49 Project Area. Bull. Org. mond. Santé Bull. Wld Hlth Org., 35: 339-356. 


\section{Orabi, et al}

Diagomanolin V, Farhang M, Ghazi-Khansari M, Jafarzadeh N. (2004): Heavy metals (Ni, Cr, Cu) in the Karoon waterway river, Iran. Toxicol Lett 151:63-68.

El-Kammar, A. M., Ali, B. H. and El-Badry, A. M. M., (2009): Environmental Geochemistry of River Nile Bottom Sediments between Aswan and Isna, Upper Egypt. J Appl Sci Res 5: 585-594

El-Khayat, H. M., Ismail, N. M., Mahmoud, K. M., Ragb, F. M., El-Said, K. M., Mostafa, B. B., El-Deeb, F. A. and Tantawy, A. A., (2011): Evaluation of some chemical parameters as potential determinants of freshwater snails with special reference to medically important snails in Egypt. World Acad. Sci., Eng. Techn., 59: 1313-1326.

El-Morsi1, D. A., Gaballah, G., Mahmoud, W. and Tawfik, A. I., (2017): Sex Determination in Egyptian Population from Scapula by Computed Tomography. Journal Forensic Res 2017, 8:3 DOI: 10.4172/2157-7145.1000376.

Farkas, A., Erratico, C. and Vigano, L. (2007): Assessment of the environmental significance of heavy metal pollution in surficial sediments of the River Po. Chemosphere, 68, 761-768.

Ferraro, L., Sprovieri, M., Alberico, I., Lirer, F., Prevedello, L. and Marsella, E., 2006. Benthic foraminifera and heavy metals distribution: a case study from the Naples Harbour (Tyrrhenian Sea, Southern Italy). Environmental Pollution, 142: 274-287.

Folk, R. L. (1966): A review of grain-size parameters. Sedimentology 6: 73-93.

Folk, R. L. and Ward, W. C., (1957): Brazos River bar: a study in the significance of grain size parameters. Journal of Sedimentary Petrology 27:3-26.

Frontalini, F. and Coccioni, R., (2011): Benthic foraminifera as bioindicators of pollution: A review of Italian research over the last three decades: Revue de Micropaléontologie, 54, 115-127.

Ghallb, M.H.M. 2007. Effect of the drains effluents on the chemical conditions of Lake Manzala and elSalam canal, Egypt. Ph. D Thesis, Faculty of Science, Ain Shams. Univ., Egypt.

Kabata-Pendias, A., (1995): Agricultural problems related to excessive trace metals content of soil. In: Heavy metals (problem and solutions). Salomons W, Förstner U, Mader P (Eds.) Springer-Verlag, Berlin, Heidelberg, New York, London, Tokyo., 3-18.

Kabata-Pendias, A., Dudka, S., Chlopecka, A. and Gawinowska, T., (1992): Background levels and environmental influences on trace metals in soil of the temperate humid zone of Europe. Adriano I (ed.) Biogeochemistry of trace metals. CRC Press, Boca Raton. Florida, USA. pp: 61-84.

Karimi, G. R., Derakhshanfar, M. and Paykari, H. (2004): Population density, trematodal infection and ecology of Lymnaea snails in Shadegan, Iran. Arch. Razi Inc., 58: 125-129.

Kazibwe, F., Makanga, B., Rubaire-Akiiki, C., Ouma, J., Kariuki, C., Kabatereine, N. B., Booth, M., Vennervald, B. J., Sturrock, R. F. and Stothard, J. R. (2006): Ecology of Biomphalaria (Gastropoda: Planorbidae) in Lake Albert, Western Uganda: snail distribution, infection with schistosomes and temporal associations with environmental dynamics. Hydrobiologia, 568: 433-444.

Khalil, M. T. and El-Awamri, A. A., (1988): Plankton organisms as bio-indicators for organic pollution at the southern area of Lake Manzala, Egypt. $1^{\text {st }}$ National Conf. Environ. Studies and Res., Cairo, Egypt 2, 526-537.

Kloos, H., de Souza, C., Gazzinelli, A., Filho, B. S. S., de Costa Temba, P., Bethony, J., Page, K., Grzywacz, C., Lewis, F., Minchella, D., Loverde, P. and Oliveira, R. C. (2001): The distribution of Biomphalaria spp. In different habitats in relation to physical, biological, water contact and cognitive factors in a rural area in Minas Gerais, Brazil. Mem. Inst. Oswaldo Cruz, Rio de Janeiro, 96:57-66.

Luciani, V., (2007): Test abnormalities in benthic foraminifera and heavy metal pollution at the Goro lagoon (Italy): a multi-year history: Geophysical Research Abstracts, 9, 09765.

Madkour, F. F. and El-Shoubaky, G. A., (2007): Spatial and temporal distribution of epiphytic diatoms on macroalgae inhabiting Port Said Coast, Mediterranean Sea, Egypt. New Egyptian Journal of Microbiology, 17: 94-105.

Mason, B. and Moore, C. B., (1982): Principles of Geochemistry. 4th edn. Wiley, New York, USA.

Mostafa, O. M. S., 2009): Effect of salinity and drought on the survival of Biomphalaria arabica, the intermediate host of Schistosoma mansoni in Saudi Arabia. Egypt. Acad. J. Bio. Sci., 1(1): 1-6.

Ofoezie, I. E., (1999): Distribution of freshwater snails in the man-made Oyan Reservoir, Ogun State, Nigeria. Hydrobiologia, 416: 181-191. 


\section{Chemical-physical and ecological characterisation}

Orabi, O. H., El-Badry, A. A. and Badr-ElDin, A. M., (2017): Benthic foraminifera for heavy metal pollution monitoring: A case study from Burullus Lagoon of Egypt. Marine Pollution Bull., 121(12), 411-417.

Pettijohn, F. J., Potter, P. E., and Siever, R., (1972): Sand and Sandstones. New York, Springer-Verlag.

Salomons, W. and Forstner, U. (1984): Metals in the Hydrocycle. Springer Verlag. Berlin. p: 349.

Shakweer, L., (2005): Ecological and fisheries development of Lake Manzalah (Egypt) hydrography and Chemistry of Lake Manzalah. Egypt. J. Aquatic Res., 31, 251-270.

Singh K. P., Malik A., Mohan D., Sinha S. (2004): Multivariate statistical techniques for the evaluation of spatial and temporal variations in water quality of Gomti River (India) a case study. Wat Res 38, 39803992.

Subba-Rao, N. V. (1993): Freshwater Molluscs of India. In: Rao KS (Ed.) Recent Advances in Freshwater Biology. New Delhi. Animal Publication 2: 187-202.

Supian, Z. and Ikhwanuddin, A. M. (2002): Population dynamics of freshwater molluscs (Gastropod: Melanoides tuberculata) in Crocker Range Park, Sabah. ASEAN Review of Biodiversity and Environmental Conservation (ARBEC).

Utzinger, J., Mayombana, C., Mez, K. and Tanner, M. (1997): Evaluation of chemical and physical morphological factors as potential determinants of omphalaria pfefferi (Krauss, 1848) distribution. Mem. Inst Oswaldo Cruz, Rio de Janeiro, 92(3): 323-328.

Vilela, C. R., Valente, V. L. S., Basso-da-Silva, L. (2004): Drosophila angustibucca Dudasensu FrotaPessoa is an undescribed species (Diptera, Drosophilidae). RevistaBrasileira de Entomologia 48(2), 233-238.

Wahby, S. D., Youssef, S. F. and Bishara, N. F. (1972): Futher studies on the hydrography and chemistry of Lake Manzalah. Bulletin of the Institute of Oceanography and Fisheries, Egypt, 2: 401-422.

Yanko, V., Arnold, A.J. and Parker, W. C., (1999): Effects of marine pollution on benthic Foraminifera, p. 217-35 In: Gupta B.K. Sen., editor. (ed.), Modern Foraminifera. Dordrecht, Kluwer Academic Publ.

Zalat, A. A. and Vildary, S. S. (2005): Distribution of diatom assemblages and their relationship to environmental variables in the surface sediments of three northern Egyptian Lakes, Journal of Paleolimnology 34:159-174. 
Orabi, et al

الخصائص الفيزيائية والكيميائية والبيئيه لمنطقة ساحلية ملوثة: حالة دراسيه لبحيرة المنزلة مصر

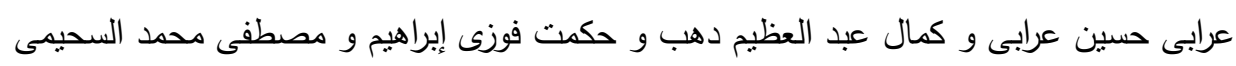

جامعه المنوفيه-كليه العلوم-قسم الجيولوجيا

الخلاصة

تهدف الدراسة الحالية لبحيرة المنزلة إلى تحديد الحالة البيئية ، حيث تلعب رخويات المباه العذبة أدوارًا هامة في الصحة

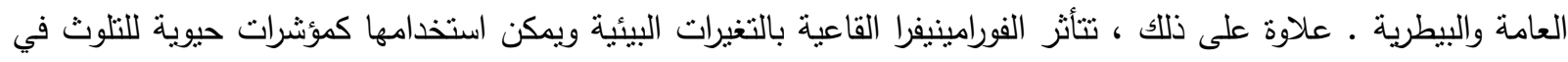

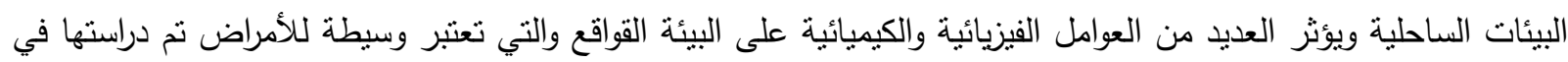
هذا العمل.

أوضحت الرواسب الحديثة الواردة في البحيرة المدروسة أن المنطقة بأكملها تتميز بفتات خشن نسبيًا (الرمال الغرينية) حيث

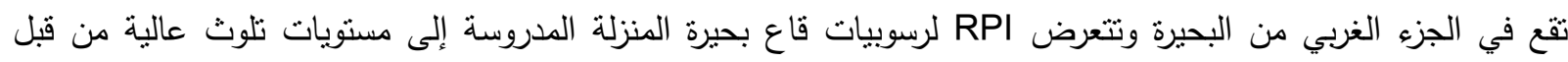

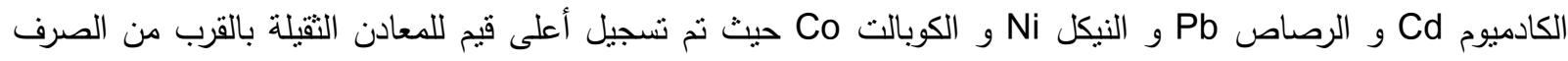
الزراعي في السرو ، وفي الجزء الثرقي من البحيرة بالقرب من مصرف بحر البقر الزراعي حيث المنطقة الصناعية في مدينه 